\title{
KONSEP PEDAGOGIK DALAM PEMIKIRAN IBNU SAHNUN DAN AL-QABISI
}

\author{
Saifullah \\ Dosen FITK UIN Ar-Raniry Banda Aceh \\ Email: saiful.ptn@gmail.com
}

\begin{abstract}
Ibn al-Qabisi Sahnun and are two classical Islamic thinkers who are very concerned about education. Ibn Sahnun was popular earlier than al-Qabisi in the $3^{\text {rd }}$ century of Islamic year, so that the world of Islamic education is heavily colored by the thoughts of the two figures. Ibn Sahnun is even known as the man who first sparked the concept of education that is independent from literary and philosophical schools of thought. The concept of education of Ibn Sahnun is oriented psychological conditions, for example in punishment. Meanwhile, al-Qabisi puts more focus on democratic educational system in the methods, curriculum or materials, procedures and other matters that are closely related to the concept of education in al-Kuttab at that time.
\end{abstract}

Keywords: pedagogy, Ibnu Sahnun and Al-Qabisi

\begin{abstract}
Abstrak
Ibnu Sahnun dan al-Qabisi adalah dua tokoh pemikir Islam klasikyang sangat konsen terhadap pendidikan. Ibnu Sahnun lebih awal popular dari pada al-Qabisi yaitu pada abad ke-3 Hijriyah, sehingga dunia pendidikan Islam banyak diwarnai oleh pemikiran-pemikiran ke dua tokoh ini. Bahkan, Ibnu Sahnun lebih dikenal sebagai orang yang pertama sekali mencetuskan konsep pendidikan yang terlepas keterkaitannya dengan sastra dan mazhab pemikiran filsafat. Adapun konsep pendidikan Ibnu Sahnun lebih berorientasi pada kondisi psikologis anak, misalnya dalam pemberian hukuman. Sedangkan, al-Qabisi lebih memokuskan pada sistem pendidikan demokratis yakni dalam hal metode, kurikulum atau materi, tata cara pembelajaran dan hal lain yang sangat terkait dengan konsep pendidikan di al-Kuttab pada saat itu.
\end{abstract}

Kata Kunci: Pedagogik, Ibnu Sahnun dan Al-Qabisi

\section{PENDAHULUAN}

Sejarah mencatat dua pemikir Islam klasik yang menuliskan pokok-pokok pemikiran pendidikan secara terpisah dari cabangcabang ilmu-ilmu lainnya. Mereka adalah Ibnu Sahnun dan Al-Qabisi. Ibnu Sahnun yang lahir pada tahun $202 \mathrm{H}$ (abad ke-3) menghasilkan banyak karya yang bisa dijadikan rujukan utama pendidikan modern. Keberadaan pemikirannya telah mampu memberi pencerahan bagi kemajuan pendidikan Islam di waktu itu. Pemikirannya ternyata masih sangat relevan untuk diaplikasikan dalam kehidupan sekarang ini. ${ }^{1}$ Sehingga abad ke-3 H, dunia pendidikan Islam banyak diwarnai oleh pemikiran-pemikiran tokoh ini. Karya Sahnun yang cukup spektakuler pada saat itu adalah kitab Adaba al-Mu'allimin. ${ }^{2}$

Kitab ini banyak mempengaruhi pemikiran al-Qabisi sebagai seorang pemikir Islam pada

${ }^{1}$ Suwito dan Fauzan, Sejarah Pemikiran Para Tokoh Pendidikan, (Bandung: Angkasa dengan UIN Jakarta Press, 2003), hal.50

2 Hasan Langulung, Asas-asas Pendidikan Islam, (Jakarta: al-Husna, 2000), hal. 230. 
abad ke-4 H. Al-Qabusi banyak mencurahkan pemikirannya terhadap pendidikan Islam. Kitab pendidikan yang dikarangnya adalah al-Mufassalh Liahwal al-Muta'allimin (Rincian tentang keadaan para pelajar, serta kode etik para guru dan pelajar). Ide-ide yang ada dalam kitab ini sangat dipengaruhi oleh tulisan Ibnu Sahnun, sampai-sampai al-Qabisi meminjam setiap kata yang digunakan oleh Ibnu Sahnun dalam kitabnya Adab al-Mu'allimin. ${ }^{3}$

Ibnu Sahnun dan al-Qabisi memang dua tokoh pemikir pendidikan Islam klasik yang cukup terkenal dan ide-idenyapun populer sampai sekarang. Kedua tokoh ini memiliki konsep pendidikan tersendiri sepanjang perkembangan ilmu pengetahuan. Oleh karena itu, dalam makalah ini penulis mencoba untuk menguraikan konsep paedagogiek yang ditawarkan oleh kedua tokoh tersebut yang dapat memberi andil bagi peningkatan khasanah intelektual kekinian.

\section{Konsep Pedagogik Ibnu Sahnun}

Sejarah mencatat bahwa orang yang pertama sekali mencetuskan pemikiran pendidikan yang terlepas dari keterkaitan dengan sastera dan mazhab-mazhab pemikiran filsafat adalah ide-ide Ibnu Sahnun. ${ }^{4}$ Tokoh ini mempunyai nama lengkapnya adalah Abd al- Salam Ibn Salam Ibn Sa'id Ibn Habib. Ia berasal dan lahir di Qairawan pada tahun $202 \mathrm{H}$, tepatnya di Afrika Utara pada masa penyebaran Islam.

\section{Pendidikan dan Tujuan Pendidikan}

PemikiranIbnuSahnuntentang pendidikan telah disebutkan antara lain sebagaimana yang terdapat dalam bukunya Adab al-Mu'allimin. Nampaknya buku ini menjadi maestro dan rujukan bagi banyak ulama, dan dianggap buku

\footnotetext{
${ }^{3}$ Hasan Langulung, Asas-asas..., hal.142.

${ }^{4}$ Jalaluddin, dkk., Filsafat Pendidikan Islam; Konsep dan Perkembangan Pemikiranya, (Jakarta: Raja Grapindo Pesada, 1994), cet.1, hal.133.
}

pertama yang membahas tentang pendidikan secara terpisah dari cabang ilmu-ilmu lainnya seperti mazhab-mazhab dan filsafat. Buku yang nampaknya ditujukan bagi pendidikan tingkat dasar ini memuat tentang adab guru dan murid dengan rujukannya Hadits Nabi yang berkaitan dengan belajar dan mengajarkan al-Qur'an. ${ }^{5}$

Dalam catatan sejarah, Ibnu Sahnun merupakan pendidik kaum muslim yang pertama sebelum ia terkenal sebagai ahli fiqh yang termasyhur di Afrika. Pemikiran pendidikannya meliputi bahasan yang sangat luas, termasuk Islam dan Aqidah Ahl Sunnah menjadi dasar pemikirannya. Pembicaraan ini telah dijelaskan dalam Adab al-Mu'allimin.

Ibnu Sahnun memang tidak mengungkapkan secara lugas tentang tujuan pendidikan, namun dalam pembicaraan dan metode pengajaran yang digunakan terungkap bahwa pembentukan etika secara umum merupakan tujuan pendidikan yang ingin dicapai oleh Ibnu Sahnun. Ia telah menjabarkan tujuan tersebut secara lebih detail dalam bukunya sebagaimana berikut: pertama, meningkatkan rasa keberagaman yang mampu membawa manusia pada pandangan egalitarianisme, kedua, menyebarluaskan ilmu agama kepada manusia, ketiga, menghasilkan ilmu dan mendapatkan ma'firah. Tujuan ini menjadi sarana untuk mencapai kedua tujuan sebelumnya, keempat, mendapatkan kedudukan dalam masyarakat, kelima, memperoleh rizki, dan keenam menyerap akhlak. ${ }^{6}$

\section{Pelaksanaan Hukuman sebagai Alat Paedagogis}

Pengalaman pendidikan semasa kecil di bawah bimbingan pengawasan sedikit banyaknya mempengaruhi pemikiran dan metode

${ }^{5}$ Tibawi, Muslim Education the Golden Age of Chalipha, Art in Islamic Culture, 28, (1954), hal. 43. dari SM Ziauddin Alavi, Pemikiran Pendidikan Islam Pada Abad Klasik dan Pertengahan, Penerjemah Abuddin Nata, Montreal, Canada, 2000, hal. 70.

${ }^{6}$ Tim Penyususn, Min 'Alam at-Tarbiyah al-Arabyah alIslamiyah, Jilid I, hal, 261. 
pengajaran yang ia terapkan. Salah satu pemikiran pendidikan Ibnu Sahnun dalam pelaksanaan pendidikan dan pengajaran kepada anak-anak adalah tentang hukuman.

\section{Konsep Pemberian Hukuman menurut Ibnu Sahnun}

Hukuman sebagai alat pendidikan sebenarnya tidak dapat terlepas dari sistem kemasyarakatan dan ketatanegaraan yang berlaku pada waktu itu. ${ }^{7}$ Sistem dan ketatanegaraan yang dimaksud tentu bagi masyarakat khususnya di Qairawan yang secara karakteristik penduduknya dikenal keras adalah peraturan atau adat istiadat. Hukuman bukan hal yang asing jika ia diterapkan dalam hal pengajaran. Masalah hukuman merupakan masalah etis, yang menyangkut soal buruk dan baik, yaitu soal norma-norma yang berlaku. Sebagai pangkal uraian selanjutnya mengenai hukuman dalam proses pendidikan dapat definisikan sebagai berikut: "Hukuman ialah penderitaan yang diberikan atau ditimbulkan dengan sengaja oleh orang tua, guru dan sebagainya sesudah terjadi suatu pelanggaran, kejahatan atau kesalahan pada setiap anak didik". ${ }^{8}$ Ibnu Sahnun ketika membahas tentang pelaksanaan hukuman sebagai alat paedagogis, menyatakan bahwa pelaksanaannya tentu harus dibatasi sesuai dengan pelanggaran atau kesalahan anak didik. Dalam hal ini Ibnu Sahnun nampaknya menyadari betul terhadap dampak-dampak psikologis yang mundul dari hukuman terhadap perkembangan jiwa anak.

Dalam suatu dialognya bersama Sa'ad, Ibnu Sahnun mengungkapkan pemikirannya tentang pemberian hukuman terhadap anak. Suatu ketika Ibnu Sahnun duduk bersama Sa'ad datanglah seorang anak perempuan Sa'ad yang menangis, dan setelah diketahui penyebab tangisan tersebut yaitu karena ia telah dipukul

7 Baisyuri Majdidi, Konsep Pendidikan Para Filosof Muslim, (Yogyakarta: Al-Amin Press, 1997), hal.24.

8 Suwito dan Fauzan, Sejarah Pemikiran Para..., (Bandung: Angkasa dengan UIN Jakarta Press, 2003), hal.55 oleh gurunya, Ibnu Sahnun kemudian berkata; "Ketahuilah demi Allah aku akan beritahukan hari ini bahwa Nabi SAW. Bersabda: "Bahwa sejahat-jahat umatku adalah mereka yang mengajar anak kecil dengan sedikit kasih sayangnya kepada anak yatim dan keras (pemarah) terhadap orang miskin."

Dalampemberianhukumanpadaanak,pada dasarnya tidak ada ulama yang menghendaki digunakan hukuman sebagai alat untuk mendidik kecuali bila terpaksa. ${ }^{9}$ Kemudian Ibnu Sahnun menambahkan bahwa hukuman yang didasarkan atas kemarahan yang tidak disertai dengan niat mendidik dan membawa manfaat merupakan perbuatan buruk yang akan mendapatkan balasan di akhirat.

Hukuman seperti memukul menurut Ibnu Sahnun dapat diberikan kepada anak didik dalam rangka tujuan mendidik asalkan tidak dilakukan secara berlebihan. Ibnu Sahnun bahkan secara tegas menyatakan bahwa hukuman yang dibolehkan harus dibatasi dalam pelaksanaannya seperti pukulan tidak boleh diberikan lebih dari tiga kali (3X) kecuali atas izin orang tua dari si anak didik yang membolehkan untuk lebih dari itu, dan itupun jika si anak terbukti telah menyakiti orang lain. $^{10}$

\section{Syarat-syarat Pemberian Hukuman}

Secara lebih jelas persyaratan-persyaratan yang diajukan oleh Ibnu Sahnun apabila guru melaksanakan hukuman adalah sebagai berikut: 1) hukuman hendaknya diberikan dengan menggunakan kasih sayang, 2) tidak memukul karena semata-mata marah, 3) pukulan itu diberikan untuk kemaslahatan anak, 4) tidak boleh memukul lebih dari tiga kali (3X), kecuali atas izin orang tua anak yang bersangkutan, 5) hendaknya memukul dengan alat yang tidak membahayakan, seperti tongkat kecil, 6) tidak sampai menyakiti fisik anak, 7) Ibnu Sahnun juga memberikan saran untuk

\footnotetext{
${ }^{9}$ Suwito dan Fauzan, Sejarah Pemikiran Para..., hal.56.

${ }^{10}$ Suwito dan Fauzan, Sejarah Pemikiran Para..., hal.57.
} 
mempertimbangkan pemberian hukuman fisik, antara lain: memperhatikan akhlak murid, menghormati hak asasi anak didik meskipun anak masih kecil, dan hendaknya tidak sembarangan dalam memberikan hukuman.

Ibnu Sahnun memahami betul tentang bahaya memberikan hukuman yang tidak terkendali terhadap perkembangan jiwa anak sehingga ia memberi batasan-batasan atau persyaratan bagi pelaksanaan hukuman sebagai alat paedagogis, yang dimaksudkan agar pendidik berhati-hati terhadap pemberian hukuman. ${ }^{11}$

\section{Dampak-dampak Pemberian Hukuman dalam Analisis Psikologis.}

Ada dua dampak pemberian hukuman, yaitu dampak negatif dan dampak positif. Beberapa dampak negatif dari pemberian hukuman adalah: pertama, menimbulkan perasaan dendam kepada si terhukum. Ini adalah akibat dari hukuman yang sewenangwenang dan tanpa tanggung jawab. Akibat semacam inilah yang harus dihindari oleh pendidik, kedua, menyebabkan anak menjadi lebih pandai menyembunyikan pelanggaran. Inipun akibat yang tidak baik, bukan yang diharapkan oleh pendidik, Memang biarpun hukuman itu baik, kadang-kadang bisa menibulkan akibat yang tidak disukai itu. Hukuman menurut teori menakut-nakuti sering menimbulkan akibat yang demikian itu. ketiga, mengakibatkan si pelanggar menjadi kehilangan perasaan salah, oleh karena kesalahannya dianggap telah dibayar dengan hukuman yang telah diterimanya, keempat, Si terhukum juga dapat memancing balasan, dan kelima, apabila hukuman ini terlalu sering dilakukan akan menimbulkan ketakutan terhadap si penghukum.

Dampak positif pemberian hukuman adalah: pertama, memperbaiki tingkah laku si pelanggar. Misalnya yang suka bercakapcakap di dalam kelas, karena mendapat

\footnotetext{
${ }^{11}$ Suwito dan Fauzan, Sejarah Pemikiran Para..., hal.57.
}

hukuman, mungkin pada akhirnya berubah juga kelakuannya, dan kedua, akibat yang lain adalah memperkuat kemauan si pelanggar untuk menjalankan kebaikan itu. Biasanya ini adalah akibat dari hukuman normatif. Sering hukuman yang demikian tidak menunjukkan akibat yang kelihatan nyata.

Nampaknya hukuman memiliki pengaruh negatif yang lebih banyak daripada positifnya. Lantas bagaimana menggunakan penghukum potensial secara efektif dan berkemanusiaan? Psikolog cenderung tidak dapat menerima hukuman fisik karena telah mengetahui akibat buruknya yang luar biasa. Oleh karenanya untuk menghindari hukuman fisik tersebut ada beberapa langkah yang dapat dilakukan, hal ini berdasarkan penelitian yang seringkali dianjurkan: 1) Ciptakan satu suasana yang bersahabat dan hangat dengan si anak, 2) Pilihlah hukuman yang sedang saja, yang secara fisik maupun psikologis tidak membahayakan anak, 3) Anda harus yakin betul bahwa anda akan dapat menguasai/ mengendalikan diri ketika melakukan hukuman, 4) Berikan hukuman ini secara konsisten bagi respon yang muncul, di manapun, 5) Arahkan hukuman ini hanya kepada tujuan sasaran perilaku yang akan diperlemah, jangan sesudahnya baru dipikirkan, 6) Buatlah hukuman sesingkat mungkin, 7) Ajarkan anak sedemikian rupa sehingga berperilaku yang baik itu dapat menghilangkan motivsi yang dapat menimbulkan respon yang tidak dikehendaki, dan 8) Buatlah pasangan yang terdiri dari penghukum potensial dengan tanda petunjuk seperti misalnya "jangan" dan "tidak". ${ }^{12}$

\section{Konsep Paedagogik Al-Qabisi.}

Dalam kontek ini perlu dijelaskan lebih dahulu bahwa pendidikan yang dijalankan al-Qabisi adalah pendidikan tingkat dasar yang berlangsung di Kuttab. ${ }^{13}$ Oleh karenanya,

${ }^{12}$ Linda L. Davidof, Psikologi Suatu Pengantar, Edisi ke2, Jilid I, (Jakarta: Erlangga), hal. 208-212.

${ }^{13}$ Istilah kuttab atau pendidikan dasar mulai dikenal pada masa awal Islam. Satu lembaga pendidikan 
konsep pendidikan yang ditawarkannyapun lebih banyak relevansinya dengan proses pendidikan pada anak. Hal ini dapat dilihat dari konsepnya tentang kewajiban mendidik anak. Menurut al-Qabisi, mendidik anak adalah kewajiban agama. Bagi orang tua yang yang mempunyai kemampuan mendidik, hendaknya ia mendidik sendiri anaknya itu, dan seandainya tidak ada kemampuan untuk itu, maka hendaknya ia mendelegasikannya kepada orang alim dan mengupahkannya. ${ }^{14}$ Kewajiban mendidik anak merupakan proses awal dari upaya peningkatan kualitas ummat. Tanpa melalui proses awal, tentu sangatlah tidak mungkin untuk mengupayakan peningkatan kualitas pendidikan dapat terealisasi dengan baik. Karena mengingat pada dasarnya anak adalah makhluk yang sedang berada dalam proses perkembangan dan pertumbuhan menurut fitrahnya masingmasing. Mereka memerlukan bimbingan dan pengarahan yang konsisiten menuju ke arah

yang diperuntukkan pada anak-anak, sehingga materi yang diajarkannyapun lebih banyak pada proses baca tulis yang dilaksanakn oleh orang-orang Kristen. Pada perkembangan selanjutnya, lembaga pendidikan kuttab tidak lagi mengajarkan proses baca tulis, namun mengajarkan juga ilmu-ilmu lainnya, seperti pengetahuan agama, ilmu berenang, cara berhitung, berkuda dan ketrampilan lainnya. Hal ini bisa dilihat dari dua jenis, kuttab berikut, yakni pertama, kuttab yang mengajarkan ilmu-ilmu non agama (secular learning); kuttab model ini biasanya lebih banyak hidup di Istana dan hanya bisa dilaksanakan oleh orang-orang yang berduit, karena guru yang mengajar merupakan guru panggilan dan harus dibayar sesuai dengan ilmu yang diajarkannya. Kedua, kuttab yang mengajarkan ilmuilmu agama (religius learning); kuttab model ini biasanya sudah mentradisi dalam kehidupan masyarakat, karena lokasinya mudah terjangkau dan diminati masyarakat pada umumnya. Pada akhirnya, lembaga pendidikan kuttab pun berimplikasi terhadap perbedaan status sosial yang ada didalam masyarakat.

${ }^{14}$ Muhammad Munir Mursi, Al-Tarbiyah al-Islamiyah Ushuluha wa Tathawuruha fi Bilad al-'Arabiyyah, Dar alMa'arif, 1987, hal. 120 titik yang optimal kemampuan fitrah ${ }^{15}$ nya. ${ }^{16}$ Dalam konteks ini, al-Qabisi berpendapat bahwa jalur pendidikan anak merupakan faktor yang signifikan sebagai penentu keberhasilan proses pendidikan. Secara garis besar, konsep pendidikan yang disuguhkan oleh al-Qabisi, meliputi hal-hal seperti tujuan pendidikan, kurikulum atau materi Pendidikan Islam, metode, teknik belajar, waktu belajar, kode etik seorang pelajar, serta profesioanlisme guru.

\section{Pendidikan Anak-anak}

Al-Qabisi memiliki perhatian yang besar terhadap pendidikan anak-anak yang berlangsung di kuttab-kuttab. Menurutnya bahwa mendidik anak-anak merupakan upaya amat strategis dalam rangka menjaga kelangsungan bangsa dan negara. Oleh karena itu, pendidikan anak harus dilaksanakan dengan penuh kesungguhan dan ketekunan yang tinggi. ${ }^{17}$

Selanjutnya ia juga dikenal sebagai ulama yang berakhlak mulia. Keluasan ilmunya yang tinggi dibarengi dengan ketekunan ibadah dan budi pekerti mulia, menyebabkan apa yang dikerjakannya kepada orang lain akan dapat diterima. Sifat inilah yang nantinya menjadi salah satu faktor pendukung keberhasilan seorang guru dalam mengajar. Guru bukan hanya menguasai berbagai materi pengajaran

${ }^{15}$ Fitrah atau dalam psikologi disebut potensialitas adalah kemampuan dasar yang secara otomatis dapat berkembang (prepotence reflexes). Dalam Islam, fitrah secara etimologis mengandung arti "kejadian", sehingga fitrah mengandung arti "kejadian" yang berisi potensi dasar beragama yang benar dan lurus. Hal ini sesuai dengan sabda Rasulullah sendiri yang artinya "tiaptiap anak yang dilahirkan dalam keadaan fitrah, maka ibu bapaknyalah yang menjadikan dia Yahudi, Nasrani, atau Majusi". Hadits tersebut menunjukkan bahwa, fitrah merupakan potensi dasar yang bisa berkembang sesuai dengan lingkungan yang mempengaruhinya, disamping faktor hereditas (keturunan) juga menentukan pertumbuhan dan perkembangan fitrah seseorang.

${ }^{16} \mathrm{H}$. M. Arifin, Ilmu pendidikan Islam, (Jakarta: Bumi Aksara, 1991), cet.7, hal. 144.

${ }^{17}$ Ali Al-Jumbulati, Perbandingan Pendidikan Islam, (Terj) H. M. ARifin, dari judul asli Dirasah al-Muqarranah $f i$ al-Tarbiyah al-Islamiyah, (Jakarta: Rineka Cipta, 1994), cet. I, hal. 87. 
dan cara menyampaikannya dengan baik, tetapi juga harus memiliki budi pekerti mulia dan keteladanan yang tinggi. Ia senantiasa menunjukkan rasa takut kepada Allah, bersih jiwanya, cinta pada fakir miskin, gemar berpuasa, shalat tahajjud, menerima apa adanya (qanaah), berhati lembut terhadap orang-orang yang mendapat musibah serta tabah dalam menderita cobaan Tuhan..$^{18}$

\section{Tujuan Pendidikan}

Sejalan dengan sikapnya yang berpegang teguh kepada agama dengan spesialisasi bidang fiqhyangberdasarkanal-Qur'an danas-Sunnah, al-Qabisi menghendaki agar pendidikan dan pengajaran dapat menumbuhkembangkan kepribadian si anak yang sesuai dengan nilainilai Islam yang benar. ${ }^{19}$ Menurutnya, bahwa nilai-nilai pendidikan agama harus bersumber dari akhlak yang mulia. Dalam Islam sendiri, agama merupakan dasar pendidikan akhlak, oleh karenanya akan menjadi suatu keharusan dalam satu pengajaran ditanamkan pendidikan akhlak. ${ }^{20}$ Hal ini sejalan dengan pendapat Syaibani yang mengemukakan bahwa "tujuan pendidikan Islam adalah mempertinggi nilainilai akhlak ${ }^{21}$, hingga mencapai tingkat akhlak al-Karimah". ${ }^{22}$ Hal ini sesuai dengan sabda Nabi

\footnotetext{
${ }^{18}$ Abudin Nata, Pemikiran Para Tokoh Pendidikan Islam, (Jakarta: Rajawali Press, 2003), hal. 27.

${ }^{19}$ Abudin Nata, Pemikiran Para Tokoh..., hal. 88.

${ }^{20}$ Muhammad Munir Mursi, Al-Tarbiyah al-Islamiyah Ushuluha wa..., Dar al-Ma'arif, 1987, hal. 121

${ }^{21}$ Istilah akhlak merupakan istilah yang lahir dari konsep al-Qur'an dan al-Sunnah (Islam) sehingga dalam aplikasi selanjutnya lebih banyak bersandar pada aturan main yang ada dalam al-Qur'an dan al-Hadits, sebagaimana diyakini oleh ummat Islam. Istilah "akhlak" sangat berbeda dengan istilah "etika" dan "moral". Karena kedua istilah tersebut secara etimologis berasal dari bahasa Yunani dan Latin (ethos untuk istilah "etika" dan "moras" untuk istilah moral) yang menunjukkan arti ilmu tentang apa yang baik dan apa yang buruk, atau nilai mengenai benar dan salah yang dianut oleh satu golongan atau masyarakat, sehingga dalam aplikasi selanjutnya etika dan moral lebih banyak bersandar pada aturan dan kesepakatan yang dibuat manusia dan masyarakat. (Lihat K.Bertens, Etika, (Jakarta: Pustaka Gramedia, 1997), cet.2, hal.5.

${ }^{22}$ Jalaluddin,FilsafatPendidikanIslam,(Jakarta:Rajawali Press, 1996), cet.2, hal. 38.
}

yang artinya "sesungguhnya aku diutus hanya untuk menyempurnakan akhlak yang mulia". Ini artinya, faktor kemuliaan akhlak dalam pendidikan Islam dinilai sebagai hal yang paling essensial dalam menetukan keberhasilan satu pendidikan.

Analisis yang bisa dikedepankan dari tujuan tersebut adalah fitrah. Anak merupakan potensi dasar yang bisa diolah menurut keinginan pendidik ${ }^{23}$--dalam hal ini orang tua dan guru--, sehingga berhasil atau tidaknya seorang anak dalam melakukan interaksi edukatif kesemuanya sangat bergantung pada tujuan awal yang disajikan oleh institusinya sesuai dengan arahan persiapan. Inilah yang sesungguhnya ingin diterapkan oleh al-Qabisi. Untuk memenuhi kebutuhan tersebut, alQabisi menyarankan satu sistem pembelajaran yang betul-betul bisa diterima anak yakni sistem pendidikan yang berjalan secara demokratis dan berorientasi pada kepentingan dan kebutuhan siswa (child oriented). Proses pendidikan ini dapat diterapkan melalui metode kasih sayang, berlaku adil dan tidak sekali-kali memberikan hukuman kepada anak tanpa alasan yang jelas. ${ }^{24}$ Tindakan demokratis yang dijalankannya telah banyak membantu menanamkan perilaku positif sebagaimana tujuan awal pendidikan itu sendiri.

Dengan demikian, proses perbaikan akhlak akan berjaan secara efektif manakala didukung sikap demokratis para pengelola pendidikan dan adanya dukungan sistem pembelajaran yang juga mendukung penanaman nilai-nilai demokrasi secara wajar.

\section{Materi Pelajaran}

Dilihat dari aspek pengajaran yang diterapkan, al-Qabisi membagi materi pelajaran ke dalam dua kategori, yaitu: mata pelajaran wajib dan mata pelajaran pilihan. Mata pelajaran

${ }^{23}$ Lihat: Q.S Ar-Rum, 30 dan Hadits kullu mauluudin yuu ladu 'ala al-fitrah...

${ }^{24}$ Muhammad Munir Mursi, Al-Tarbiyah al-Islamiyah Ushuluha wa..., Dar al-Ma'arif, 1987, hal. 122. 
wajib adalah membaca dan menulis al-Qur'an, ${ }^{25}$ termasuk di dalamnya terdapat bacaanbacaan shalat, ${ }^{26}$ ditambah dengan penguasaan terhadap ilmu Nahwu dan bahasa Arab yang keduanya merupakan prasyarat untuk memantapkan bacaan al-Qur'an. Alasan utama Al-Qabisi mamasukkan pelajaran membaca dan penulis al-Qur'an ke dalam mata pelajaran wajib adalah karena al-Qur'an merupakan kalam Allah dan menjadi sumber hukum tasyri'. Di samping karena al-Qur'an juga merupakan rujukan utama kaum muslimin dalam masalah ibadah dan mu'amalat. ${ }^{27}$

Mata pelajaran pilihan adalah materi pelajaran alternatif atau pilihan. Artinya tidak ada kewajiban bagi siswa untuk mengambil mata pelajaran model ini. Dalam kurikulum ini terdapat beberapa materi pelajaran seperti ilmu hitung (hisab), fiqh, penguasaan ilmu nahwu dan bahasa Arab secara lengkap, syi'ir, kisah-kisah bangsa Arab serta sejarah. Materimateri tersebut merupakan pendorong untuk mengkaji ilmu-ilmu tertentu dan sebagai alat untuk menuangkan bakat dan potensi yang dimiliki seorang anak.

Materi pilihan yang ditawarkan alQabisi, begitu sarat dengan kepentingan dan pengembangan potensi (bakat) siswa. Misalnya pelajaran berhitung yang kemudian dikenal dengan ilmu matematika merupakan salah satu pelajaran yang mampu mengembangkan cara berfikir anak secara sistematis, logis dan teratur. Sehingga pada proses akhirnya akan dapat melahirkan anak yang jujur, patuh dan taat pada aturan, baik kepada orang tua, agama maupun aturan-aturan lain. Oleh karenanya, materi ilmu hitung akan sangat membantu seorang anak dalam memahami al-Qur'an. Dengan demikian, al-Qabisi menghendaki pendidikan yang betul-betul komprehensif, menyeluruh dan tidak parsial. Karena ilmu

${ }^{25}$ Amir Syamsuddin, al-Fikr 'Inda Ibn Syahnun wa alQabisi, Dar Iqra, hal.88

${ }^{26}$ Amir Syamsuddin, al-Fikr 'Inda..., hal. 89

${ }^{27}$ Muhammad Munir Mursi, Al-Tarbiyah al-Islamiyah Ushuluha wa..., Dar al-Ma'arif, 1987, hal. 120. pada dasarnya satu sama lain saling berkaitan. Tidak ada perbedaan antara ilmu agama dengan non agama. Informasi ini dapt dibaca pada persoalan dualisme ilmu pengetahuan, seperti yang sudah pernah terjadi pada masamasa awal perkembangan madrasah ${ }^{28}$ atau al-Jami'ah ${ }^{29}$ atau masa sesudah beliau meninggal dunia, sehingga dalam pendidikan manapun, tingkat dasar, menengah, maupun tingkat perguruan tinggi sudah seharusnya menawarkan mata pelajaran yang dikonsepsikan al-Qabisi.

\section{Metode dan Teknik Belajar}

Al-Qabisi menjelaskan bahwa pertamatama anak harus diajari membaca dan menghafal al-Qur'an. Jika kedua skil ini sudah mantap, kemudian baru diajari menulis, ditambah lagi dengan pelajaran-pelajaran lainnya. Metode menghafal yang dianjurkan oleh al-Qabisi itu didasarkan pada pemahaman sebuah hadits Nabi Saw. tentang menghafal al-Qur'an. Nabi mengumpakan orang yang menghafal al-Qur'an bagaikan unta yang diikat dengan tali, jika pemiliknya mengokohkan ikatannya, unta itu akan terikat erat pula, dan jika ia melepaskan tali ikatannya, maka ia akan pergi." Jika orang yang menghafal al-Qur'an di waktu malam dan di siang hari mengulangngulanginya, maka ia akan tetap mengingatnya, dan jika ia tidak pernah membacanya, maka ia akan melupakannya (hilang hafalannya). ${ }^{30}$

Atas dasar hadits tersebut, al-Qabisi menyatakan "sesungguhnya Rasulullah menjelaskan dalam haditsnya tersebut di atas tentang cara-cara mengingat yang dapat memantapkan hafalan-hafalan al-Qur'an, sehingga ia tak perlu belajar berulang-

28 Madrasah yang dimaksud adalah Madrasah Nidzamiyah. Madrasah ini didirikan oleh Nizam al-Mulk pada abad ke-5 Hijriah (ke-11 M) bertepatan dengan tahun 450 H. (Lihat Maksum, Madrasah: Sejarah dan Perkembangannya, (Jakarta: Logos, 2000), hal.60.

${ }^{29}$ Lihat: Azyumardi Azra, Pendidikan Islam: Tradisi dan Modernisasi Menuju Millenium Baru, (Jakarta: Logos, 1999), hal. 9.

30 Abudin Nata,Pemikiran Para Tokoh..., (Jakarta: Rajawali Press, 2003), hal. 35. 
ulang lagi. Ucapan al-Qabisi ini memberikan petunjuk tentang tahapan-tahapan dalam metode mempelajari dan memahami al-Qur'an, yaitu dimulai dengan menghafal kalimat, kemudian memahami isinya dan setelah itu mengulangi kembali hafalan tersebut hingga mantap. Untuk menghasilkan yang demikian itu diperlukan kecenderungan (al-Mail) yakni daya tarik yang kuat.

Dari uraian di atas, dapat penulis analisis bahwa adanya penerapan metode dalam satu proses pendidikan di setiap jenjang, baik dasar maupun perguruan tinggi, harus betulbetul disesuaikan dengan materi pelajaran yang bersangkutan, situasi dan kondisi serta kemampuan guru yang mengajar. Di samping ada pemahaman dari penulis kalau dalam mengajar. Di samping ada pemahaman dari penulis kalau dalam belajar sesungguhnya harus sistematis, gradual atau tahap demi tahap. Hal ini sangat nampak pada pemikiran al-Qabisi yang tidak memperbolehkan seorang mengizinkan anak berpindah dalam belajar alQur'an sebelum hafal betul.

\section{Prinsip-Prinsip Pendidikan}

Prinsip yang ditawarkan oleh al-Qabisi dalam persoalan pendidikan lebih menyangkut pada persoalan asasi sebuah institusi pendidikan agama. Dalam konteks ini ada beberapa prinsip yang diaplikasikan oleh alQabisi. Pertama, mengenai larangan belajar di luar agama. Point ini kelihatannya al-Qabisi punya kesamaan visi dengan Ibnu Sahnun, keduanya melarang (anak-anak) non muslim yang mau belajar di kuttab. Begitupun sebaliknya, anak-anak yang beragama Islam juga dilarang mengikuti pengajaran di sekolahsekolah Nasrani..$^{31}$ Di satu sisi kelihatan sekali kalau al-Qabisi masih menggunakan pola pemikiran normatif dalam mengatur interaksi edukatif yang ada di kuttab. Namun pada sisi yang lain, dapat dianalisis kalau sesungguhnya,

${ }^{31}$ Muhammad Munir Mursi, Al-Tarbiyah al-Islamiyah Ushuluha wa..., Dar al-Ma'arif, 1987, hal. 123. anak-anak yang masih di bawah umur masih sangat labil dalam berfikir, dan rentan untuk berpindah idiologi. Oleh karena itu, penulis sangat memaklumi kalau misalnya pada saat itu, baik al-Qabisi maupun Ibnu Sahnun melarang anak-anak Muslim belajar di luar institusi pendidikannya.

Kedua, tanggung jawab pendidikan. AlQabisi juga berpandangan bahwa kewajiban mengajarkan al-Qur'an kepada anak-anak adalah tanggung jawab orang tua, namun ketika orang tuanya tidak mampu mengajari anak-anaknya, maka orang tua berkewajiban menyuruh anak-anak belajar kepada orang lain atau mendatangkan guru al-Qur'an. Jika tidak mampu juga, maka hendaklah orang tua dibebankan kepada bait al-mal.32 Dengan demikian dapat diambil pemahaman bahwa yang menjadi penanggung jawab pendidikan adalah orang tua, guru dan pemerintah. Orang tua sebagai pendidik utama. ${ }^{33}$ Dalam persoalan ini al-Qabisi berpendapat bahwa seharusnya (yang pertama kali) berkewajiban memberikan pengajaran adalah kedua orang tua. Kewajiban tersebut akan sama halnya orang tua memberikan nafkah untuk kehidupan mereka. ${ }^{34}$ Guru sebagai pendidik kedua. Guru merupakan pengganti orang tua $a^{35}$ dalam urusan pendidikan. Oleh karena itu, menurut alQabisi, ada beberapa hal yang harus dilakukan oleh seorang guru, antara lain: harus memiliki sifat kasih sayang, bersikap adil, beretika, memiliki planning atau visioner, serta mengerti akan kebutuhan anak. $^{36}$ Kriteria tersebut sesungguhnya awal dari adanya tanggung jawab yang sama antara orang tua dan guru dalam mendidik anak, sehingga bagi al-Qabisi seorang guru

${ }^{32}$ Amir Syamsuddin, al-Fikr 'Inda Ibn Syahnun wa alQabisi, Dar Iqra, hal. 83

33 Pendidik sebagaimana dijelaskan WJS. Poerwadarminta adalah yang mendidik (kamus umum bahasa Indonesia, 1991, hal. 250). Pengertian tersebut mengisyaratkan kepada kita semua bahwa pendidik tidak hanya terbatas pada guru.

${ }^{34}$ WJS. Poerwadarminta, Kamus Umum..., 1991, hal. 88

${ }^{35}$ Suwito dan Fauzan, Sejarah Pemikiran Para Tokoh..., (Bandung: Angkasa dengan UIN Jakarta Press, 2003), hal.106 85. 
haruslah betul-betul manusia alim dan mampu mempertahankan komitmen keguruan yang lumayan besar.

Dengan demikian penulis dapat memahami bahwa pendidikan yang baik harus ditopang oleh adanya kerja sama yang baik antara orang tua dengan guru. Karena pendidikan tidak dibebankan ada satu institusi tertentu, yakni sekolah. Akan tetapi harus melibatkan beberapa institusi lain, seperti rumah, lingkungan sekitar dalam rangka menjadikan anak tumbuh dan berkembang sesuai dengan harapan semua pihak. Jadi, proses pendidikan harus dimulai oleh orang tua di rumah, kemudian dilanjutkan oleh guru sebagai pendidik di sekolah. Dengan demikian pendidikan tidak lagi menjadi tanggung jawab guru sekolah, akan tetapi ada penanggung jawab lain yang seharusnya mempunyai peran penting dalam rangka pembentukan watak anak, yaitu orang tua.

\section{Percampuran Belajar Antara Murid Laki- laki dan Perempuan}

Percampuran belajar antara murid lakilaki dan perempuan dalam satu tempat atau yang dikenal dengan istilah Co-Educational Classes juga menjadi perhatian al-Qabisi.Ia tidak setuju bila murid laki-laki dicampur dengan murid perempuan di kuttab, sehingga anak itu harus tetap belajar sampai usia baligh (dewasa). Menurut al-Qabisi bahwa bercampurnya anak laki-laki dan perempuan di kuttab untuk belajar adalah suatu hal yang tidak baik. Pendapat ini tampak kelihatan kuno dan tidak dapat diterima masyarakat modern yang menuntut kesamaan derajat dan kemitraan sejajar. Dalam hubungan ini al-Qabisi menilai sesungguhpun pendapatnya terkesan kuno, namun pendapat itulah yang sesuai dengan garis ajaran agama Islam. Karena anak yang berusia muharrigah (masa puberitas/remaja) tidak memiliki ketenangan jiwa dan timbul dorongan kuat untuk mempertahankan jenis kelaminnya hingga sampai waktu dewasa.
Al-Qabisi sebagaimana halnya Ibnu Sahnun (abad $3 \mathrm{H}$ ), sependapat bahwa guru yang paling tidak disukai adalah guru yang megajarkan anak-anak perempuan remaja, kemudian mereka dicampur dengan anak lakilaki remaja. Hal demikian akan menimbulkan kerusakan bagi anak perempuan remaja. Salah satu alasan mengapa Al-Qabisi berpegang teguh pada pendapatnya itu adalah karena ia kawatir kalau anak-anak itu menjadi rusak moralnya. Ia memperingatkan agar tidak mencampurkan anak kecil dengan remaja yang telah dewasa (telah bermimpi coitus), kecuali bila anak remaja yang telah baligh tidak akan merusak anak kecil. Sikap al-Qabisi yang tidak sependapat dengan bercampurnya anak laki-laki dengan perempuan dalam satu tempat dalam belajar itu, antara lain didasarkan pada pandangannya bahwa dorongan syahwat biologis (seksual) termasuk dorongan yang paling kuat, dan jika berdekatan dengan wanita dikhawatirkan akan terjadi pelanggaran seksual yang dapat merendahkan martabatnya dan menjauhkan dari keimanan dan ketaqwaan yang ada dalam dirinya. Dengan demikian, sikapnya itu tampak lebih didasarkan pada sikap yang amat berhati-hati dalam menjaga moral agama. Di sini terlihat dengan jelas betapa prinsipnya yang demikian kuat berpegang kepada agama dan taat beribadah kepada Allah. ${ }^{37}$

\section{Kurikulum}

Kurikulum pendidikan yang ditawarkan oleh al-Qabisi lebih diorientasikan pada kepentingan siswa (child oriented) bukan pada kepentingan guru. Mata pelajaran wajib seperti membaca dan menulis al-Qur'an bagi seorang anak akan menjadi hal yang urgen. Karena bagi seorang mubtadiin, menulis dan membaca merupakan aktivitas awal yang akan banyak membantu proses pemahamannya terhadap isi

${ }^{37}$ Abudin Nata, Pemikiran Para Tokoh..., (Jakarta: Rajawali Press, 2003), hal. 36-37. 
kandungan al-Qur'an, termasuk peningkatan ilmu pengetahuan lainnya. ${ }^{38}$

\section{Kurikulum Ijbari (wajib)}

Kurikulum yang terdiri dari pada kandungan ayat-ayat Al-Qur'an seperti ayatayat sembahyang dan do'a-do'a. Sebagian para ahli mengatakan bahwa ilmu Nahwu dan bahasa Arab, keduanya merupakan persyaratan mutlak untuk memantapkan baca Al-Qur'an, tilawah, menulis dan hafalan. Al-Qabisi lebih lanjut mengatakan bahwa dimasukkannya pelajaran membaca dan menulis Al-Qur'an ke dalam kurikulum ijbari adalah karena Al-Qur'an merupakan kalam Allah dan menjadi sumber hukum dan tasyri'. Al-Qur'an menjadi referensi (rujukan) kaum muslimin dalam masalah ibadat dan mu'amalat. Allah mendorong semangat untuk beribadah dengan membaca Al-Qur'an sebagai berikut

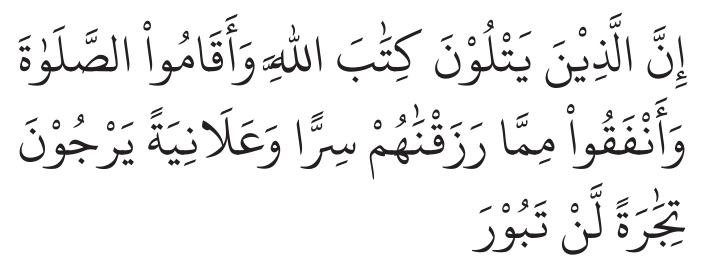

"Sesungguhnya oran-orang yang membaca kitab Allah dan mendirikan sembahyang dan membelanjakan hartanya ke jalan Allah setengah dari apa yang kami rezekikan kepada mereka baik dengan cara diam-diam (rahasia) maupun dengan cara teran-terangan mereka mengharapkan usaha dagangnya tidak menderita kerugian." (Q.S al-Fathir: 29)

Menurut al-Qabisi bahwa ayat tersebut dengan jelas menyuruh umat manusia, agar membaca al-Qur'an, mendirikan shalat dan berbuat baik (akhlak yang mulia) dilakukan secara serempak, tidak terpisah satu sama lainnya. Lebih lanjut al-Qabisi mengatakan

${ }^{38}$ Suwito dan Fauzan, Sejarah Pemikiran Para Tokoh..., (Bandung: Angkasa dengan UIN Jakarta Press, 2003), hal.103. bahwa di dalam pelaksanaan shalat yang merupakan tiang agama dibaca ayat-ayat al-Qur'an. Itulah sebabnya kemampuan membaca, menulis dan memahami al-Qur'an merupakan persyaratan untuk melaksanakan kewajiban shalat lima waktu' selain itu di dalam al-Qur'an terkandung pula petunjuk dan ajaran utama mengenai berbagai masalah yang dihadapi manusia. Pendapat al-Qabisi tentang pentingnya pelajaran membaca dan memahami al-Qur'an dalam hubungannya dengan shalat menggambarkan dengan jelas tentang kecenderungan sebagai seorang ahli fiqih.

Lebih lanjut al-Qabisi melihat bahwa dengan mengintegrasikan antara kewajiban mempelajari al-Qur'an dengan sembahyang dan berdoa, berarti telah mengintegrasikan antara aspek berpikir, merasa dan berbuat (beramal). Prinsip kurikulum demikian itu sesuai dengan pandangannya mengenai ilmu jiwa yang ditetapkan melalui tiga prinsip yang logis, yaitu; (1) Menumpahkan perhatian untuk menambah makrifat kepada Allah serta mendekatkan kepada-Nya. (2) Pentingnya ilmu Nahwu (grammar) bagi anak agar dapat memahami kitab suci Al-Qur'an secara benar. (3) Mengajarkan bahasa Arab sebagai alat memahami makna ayat Al-Qur'an beserta huruf hijaiyahnya agar anak dapat menuliskan ayat-ayatnya dan mengucapkannya dengan lancar.

Uraian kurikulum menurut pandangan al-Qabisi yang telah disebutkan di atas adalah lebih cocok untuk jenjang pendidikan dasar, atau pra-dasar, yakni pendidikan di al-kuttab, sesuai dengan jenjang yang telah dikenal pada masa itu. Kurikulum tersebut masih cocok dipakai pada jenjang pendidikan tingkat dasar hingga pada masa sekarang. ${ }^{39}$

${ }^{39}$ Abuddin Nata, Pemikiran Para Tokoh..., (Jakarta: Raja Grafindo Persada, 2000) hal 30. 


\section{Kurikulum Ikhtiari (Tidak Wajib/Pilihan)}

Kurikulum ini berisi ilmu hitung dan seluruh ilmu Nahwu, bahasa Arab, syair, kisahkisah masyarakat Arab, sejarah Islam, ilmu Nahwu (grammar), dan bahasa Arab lengkap. Lebih lanjut Al-Qabisi mengemukakan bahwa perbedaan antara ilmu-ilmu ikhtiari ini dengan ilmu ijbari adalah dari segi jarak jauh dekatnya ilmutersebut untuk pembinaan rasakeagamaan yang kuat, dimana ilmu-ilmu jabariah lebih dekat jaraknya dengan pembinaan keagamaan. Disinilah letak begitu kuatnya dengan motivasi keagamaan dalam merumuskan konsep kurikulumnya. Dalam kurikulum ikhtiari ini al-Qabisi memasukkan pelajaran ketrampilan yang dapat menghasilkan produksi kerja yang mampu membiayai hidup di masa yang akan datang. Dengan demikian menurut pandangan al-Qabisi bahwa memberikan pelajaran ketrampilan kerja untuk mencari nafkah hidup sesudah selesai tiap jenjang pendidikan yang ditempuh dengan dasar pengetahuan al-Qur'an serta ketaatan dalam menjalankan ibadah menunjukkan adanya pandangan yang menyatukan antara tujuan pendidikan keagamaan dengan tujuan pendidikan pragmatis.

\section{Demokrasi dalam Pendidikan}

Selanjutnya al-Qabisi memiliki pandangan tentang demokrasi dalam pendidikan. Menurut al-Qabisibahwaanak-anakyangmasuk diKuttab tidak ada perbedaan derajat atau martabat. Baginya pendidikan adalah hak semua orang tanpa ada pengecualian. Ia menghendaki agar penyelenggaraan pendidikan anak-anak muslim dilaksanakan dalam satu ruang dan memperoleh pengetahuan dari pendidikan yang satu, sehingga tidak perlu dibagi-bagi menjadi tingkat atau jenjang. Pendapatnya yang demikian mengisyaratkan adanya paham demokrasi dalam pendidikan. al-Qabisi juga mengatakan bahwa antara anak laki-laki dan perempuan memiliki hak yang sama dalam memperoleh pendidikan. Menurutnya bahwa pendidikan bagi anak-anak perempuan merupakan suatu keharusan, sama dengan pendidikan bagi anak laki-laki, meskipun harus dipisahkan kelasnya antara keduanya sebagaimana yang telah diuraikan di atas.

Sejalan dengan pendapatnya di atas, alQabisi mengatakan bahwa kewajiban mengajar itu adalah kewajiban agama, yang tidak membeda-bedakan tingkatan dan kedudukan sosial di masyarakat. Untuk mendukung terlaksananya demokasi atau pemerataan dalam pendidikan, al-Qabisi menganjurkan agar orang-orang Islam yang berkemampuan material hendaknya mau membantu atau menolong semacam bantuan pendidikan kepada anak-anak yang kurang mampu.

Oleh karena itu, bila dikaji risalah al-Qabisi dari aspek pendidikan modern pada masa kini, maka akan diketemukan di dalamnya suatu pandangan yang terlalu berani, meskipun sebelumnya telah muncul berbagai pendapat tentanghal-halserupa.Namunal-Qabisitampak bersikap lebih hati-hati dalam mengemukakan pendapat-pendapatnya sehingga tetap sejalan dengan arus zaman di mana ia hidup, yakni alQabisi tetap memasukkan jiwa agama dalam konsep pendidikan tersebut. Inilah agaknya yang menjadikan pendapatnya sangat sejalan dengan pandangan agama dalam pendidikan. Demikian kuatnya berpegang teguh pada agama, sehingga al-Qabisi sebagaimana halnya Ibnu Sahnun melarang non-muslim untuk belajar di lembaga pendidikan orang Islam, dan melarang orang Islam belajar di lembaga pendidikan Nasrani, karena hal itu dapat mengacaukan jiwa agamanya. ${ }^{40}$

\section{PENUTUP}

Konsep pendidikan yang dikemukakan oleh Ibnu Sahnun lebih ke arah pemahaman psikologis anak seperti yang dijelaskan dalam bukunya adab al-Mu'allimin, yang membahas tentang adab belajar dan mengajar, yang di

\footnotetext{
${ }^{40}$ Abuddin Nata, Pemikiran Para Tokoh..., hal. 38-41.
} 
dalamnya dibahas pula tentang hukuman dalam pendidikan. Sedangkan al-Qabisi lebih cenderung menerapkan corak pendidikan demokratis dalam mengaplikasikan proses pembelajaran di kuttab, baik itu dalam rangka merealisasikan tujuan pendidikan, kategori mata pelajaran yang diterapkan, maupun kurikulum yang diaplikasikan. Namun ruang lingkup pembahasannya sama-sama pada proses pendidikan anak yang ada di kuttab yaitu pendidikan dasar.

\section{SUMBER BACAAN}

Azyumardi Azra, Pendidikan Islam: Tradisi dan Modernisasi Menuju Millenium Baru, Logos, Jakarta, 1999.

Abudin Nata, Pemikiran Para Tokoh Pendidikan Islam, Rajawali Press, Jakarta, 2003.

Amir Syamsuddin, al-Fikr 'Inda Ibn Syahnun wa al-Qabisi, Dar Iqra.

Arifin, M, H., Ilmu pendidikan Islam, Bumi Aksara, Jakarta, 1991.

--------, Dirasah al-Muqarranah fi alTarbiyah al-Islamiyah,Rineka Cipta, cet. I, Jakarta, 1994.

Ali al-Jumbulati, Perbandingan Pendidikan Islam, (Terj.) H.M Arifin, M.Ed, dari judul asli Dirasat al-Mugaranah fi al-Tarbiyah alIslamiyah, Rineka Cipta, Jakarta, 1994.

Baisyuri Majdidi, Konsep Pendidikan Para Filosof Muslim, Al-Amin Press, Yogyakarta, 1997.
Hasan Langulung, Asas-asas Pendidikan Islam, alHusna, Jakarta, 2000.

Jalaluddin, dkk, Filsafat Pendidikan Islam; Konsep dan Perkembangan Pemikiranya, Raja Grapindo Pesada, Jakarta, 1994.

-------,Min 'Alam at-Tarbiyah al-Arabyah alIslamiyah, Jilid I.

--------, Filsafat Pendidikan Islam, Rineka Cipta, Jakarta 1996.

K.Bertens, Etika, Pustaka Gramedia, Jakarta, 1997.

Linda L. Davidof, Psikologi Suatu Pengantar, Edisi ke-2, Jilid I, Erlangga, Jakarta, 1998.

Muhammad Munir Mursi, Al-Tarbiyah alIslamiyah Ushuluha wa Tathawuruha fi Bilad al-'Arabiyyah, Dar al-Ma'arif, 1987.

Maksum,Madrasah:SejarahdanPerkembangannya, Logos, Jakarta, 2000.

Poerwadarminta, W.J.S, Kamus Umum Bahasa Indonesia, 1991.

Suwito dan Fauzan, Sejarah Pemikiran Para Tokoh Pendidikan, Angkasa dengan UIN Jakarta Press, Bandung, 2003.

Tibawi, Muslim Education the Golden Age of Chalipha, Art in Islamic Culture, 28, 1954, dari SM Ziauddin Alavi, Pemikiran Pendidikan Islam Pada Abad Klasik dan Pertengahan, Penerjemah Abuddin Nata, Montreal, Canada, 2000. 